\title{
An Evaluation of Electronic ID Card Program to Improve Public Service Quality at Department of Population and Civil Registration Kediri City
}

\author{
Wahyu Setyaningrum ${ }^{1}$, Andy Fefta Wijaya ${ }^{2}$, Suryadi $^{3}$ \\ 1. 2. 3. Faculty of Administrative Science, University of Brawijaya, 163 MT. Haryono Street, Malang 65145, \\ Indonesia \\ * E-mail of the corresponding author: wahyusetyaningrum93@yahoo.co.id
}

\begin{abstract}
The development of e-ID card in Kediri City has improved to a higher level (The Ministry of Domestic Affairs of Indonesia) of e-government application in the local area. The research problems of this study are; firstly, it was related to the concept of the e-service on the e-ID card program in the efforts of service quality improvement; and secondly, it was related to the influence factors of the e-ID card program implementation in the efforts of service quality improvement. The research data and information were collected by an intensive observation, indepth interview, and documentation. The research was also analyzed by the qualitative approach and discussed by the evaluation concept as a grand theory of analysis. The research results were derived from the research problems that concluded two main analysis results; firstly, Department of Population and Civil Registration used the Information and Technology (IT) based governance that has lead to the implementation of e-service. Secondly, The restraining factors also relate to the external and internal factors, such as; infrastructures, organizational structures, skill of the employees, and program socialization. The external factor came up from the low awareness and interest of community.
\end{abstract}

Keywords: Public Service Quality, e-Government, e-Service, Evaluation

\section{Introduction}

Since the enactment of the law no. 32 of 2004 on local government, there is autonomy from the central government handed over to local authorities. Local governments were given the authority to regulate its own country in accordance with the broad principles, real, and responsibility. Through decentralization (devolution) or autonomous public service wide, hope getting maximum performance. First, the assumption that the smaller the geographical scope and the number of people served the easier to organize services to the community. Second, with extensive autonomy, broader government authority anyway. As expressed by Litvack (1998) in (Kartiwa, 2012, p.93), which says that the most efficient public services organized by geographical area which covers the minimum, because local governments live up to the needs of society and the decision of the local government is very responsive to the needs of the community, thus encouraging local governments to improve efficiency in the use of funds from the public.

Local governments in charge of ensuring the public services that are effective, efficient and accountable. Effectiveness associated with the inputs and outputs where the achievement of the main goal of the government program. Efficiency associated with the input and output where there is a correct use of the funds to the provision of services. Various attempts were made to local governments to provide maximum service. Local governments in the service of the division of labor is divided into some program that achieved the main goal

The population administration become important thing because always contacts with each human activities in Indonesia. For example, it will be used during legislative election, presidential election, local election, and for vehicles administration, land administration, and other. If we are domiciled at certain area, we should have the domicile card that is proven by the Identity Card (ID). The eIDcard program is based on the conventional ID making system in that make possible for someone to has more than one ID. It is caused by no integrated data base that collects population data from all Indonesia. The facts give opportunities for someone to do fraudulent in certain case by doubling his ID. For example can be used to avoid tax, hide identity (such as terrorist) and falsify and double the ID.

In fact, in general, the quality of public services in Indonesia has not given satisfaction to the public as users of the service. In 2002, the survey results indicate that the University of Gajah Mada several surveys conducted by 
various agencies report card also showed poor public services in Indonesia, such as those shown in the table below:

Table.1.Report of Public Services Quality in Indonesia

\begin{tabular}{|l|l|l|}
\hline Name Institution & Year & Order Indonesia \\
\hline $\begin{array}{l}\text { World Investment Report: } \\
\text { Index Foreign Direct } \\
\text { Investment 1999-2001 }\end{array}$ & 2003 & $\begin{array}{l}\text { Indonesia sequence of 139 countries in Asia } \\
\text { and } \\
\text { Africa }\end{array}$ \\
\hline $\begin{array}{l}\text { Human Development } \\
\text { Report, UNDP }\end{array}$ & 2002 & $\begin{array}{l}\text { Indonesia sequence to 106 of 110 countries, in } \\
\text { the Philippines, China and Vietnam. }\end{array}$ \\
\hline $\begin{array}{l}\text { Country Risk (Marvin } \\
\text { Zonish \& Associate) }\end{array}$ & - & $\begin{array}{l}\text { Indonesia sequence to 150 of 185 countries, } \\
\text { under Afghanistan, Burundiand Somalia. }\end{array}$ \\
\hline $\begin{array}{l}\text { World Bank's Chief } \\
\text { Representative } \\
\text { Steer) Andrew }\end{array}$ & 8 June 2004 & $\begin{array}{l}\text { Indonesia finished last in Asia for the level of } \\
\text { electricity usage, 9th of 12 countries for mobile } \\
\text { phone customers, order-7 for access to } \\
\text { sanitation, the order-8 for road access and } \\
\text { order-7 for the water to reach 16\% of the } \\
\text { population. }\end{array}$ \\
\hline World Development Report & 2004 & $\begin{array}{l}\text { People's access to public services is still low } \\
\text { (education, health, and water supply) }\end{array}$ \\
\hline
\end{tabular}

Source: (Puspitosari et al, 2012, p.127)

In making ID, the Sub-District Kota still not getting good service. Community care getting long time. Community of Kediri City complained many regular ID card service in the office of and Civil. Besides the process takes a long time, people were fined 50 thousand IDR when the ID card expires, and 150 thousand IDR for the ID card is lost. Basuni, Setono Pande Villagers Kediri, while in office ID Population and civil registration Departmen of Population and Civil Registration Kediri City, complained about the lack of socialization related penalty rules for ID card is lost or dead. Penalty policy was very burdensome to the community, especially among the economically weak.(www.bonansafm.com)

The government needs to make improvements in policy programs, especially in the public service program. The government needs to reform public services. More and better public services will create economic, efficiency and effectiveness in service. Departing from the real conditions on the author considers the need for evaluation of e-ID card program in an effort to improve the quality of public services in the Department of Population and Civil Registration Kediri City, so that later we can see the results of the evaluation of e-service and influence factors of the electronic identity card program. In the e-ID card program evaluation, the researchers wanted to determine the effectiveness of program components in supporting the achievement of program objectives in the Government Kediri city.

\section{Literature Review}

\subsection{Public Service Quality}

The administrative science theories taught that state government basically implement two main functions, regulating and services functions. The regulating functions usually related with the modern state as legal state, while the services functions are related with the essence of welfare state. Either the regulating functions or services functions relate with all life aspects, and the implementation is given to the certain governmental apparatus and functionally responsible to certain field of both functions. (Siagian, 2001, p. 28-129) in (Hardiansyah, 2011, p.104)

In the public service, there are several factors driving/supporting each other and affect together to realize the implementation of good service, a service of verbal, services in the form of movement/action with or without equipment. Factors that support public services proposed by (Moenir, 2006, p.88-123), namely: (1). Awareness of officials and officers, (2). Rules that underlie service work, (3). Organization, (4). Revenue of officer, (5). Abilities and skills of personnel, and (6). The ingredients in the implementation of the service assignment.

Zeithaml et.al (1990, p.26) in Hardiyansyah (2011, p.42) describe SERVQUAL dimension for public service quality, there are five indicator: (1) Tangibles, Apperance of physical facilities, equipment, perosonnel, and communication materials; (2) Reliability, Ability to perform the promied service dependably and accurately; (3) 
Responsivenes, Willingness to help customers and provide prompt service; (4) Assurance, Knowledge and courtesy of employees and their ability to convey trust and confidence; and (5) Emphaty, The firm provides care individualized attention to its customer.

\subsection{E-Government}

Terminology of "e-government" means as a group of concept for all actions in public sector (either at central or local government level) that involve information and communication technology in effort to optimize the public services efficiently, transparently and effectively (Kurniawan, 2006) in (Hardiyansyah, 2011, p.107).

There are various electronic government service type that is offered by government to the society. Indrajit (2002, p.29-34), explained that one way to categorize the service type by looking at two (2) main aspects: (1) Complexity aspects, that relates with the complex anatomy of electronic government application, and (2)Benefit aspects, that relates with the felt benefit by societies.

Based on the two aspects above, then the type of electronic government can be divided into three (3) classes, that is (1) Publish: The type is implementation of the easiest electronic government because beside the small project scale, most the application no need to involve all great and diverse resources. (2) Interact: The class provides two way communication between government and the stakeholders. (3) Transact: The class is two way interaction as in the interact class, there is transaction that relates with the money transfer from one party to others.

\subsection{E-Service}

There are various definitions given to the e-Service. For example, Reynolds (2000) in (Sukasame, 2004 p.1) views an electronic service or e-Service as the web-based service delivered through the Internet. According to de Ruyter et al. (2000) in (Sukasame, 2004 p.1), an e-Service is an interactive, content-centered and internetbased customer services, driven by the customer and integrated with related organizational customer support processes and technologies with the goal of strengthening customer-service provider relationship. In addition, Surjadjaja et al. (2003) in (Sukasame, 2004, p.1) states that the concept of e-Service is not simply a combination of the words 'electronic' and 'service'. In a true e-Service operation part or all of the interaction between the service provider and the customer is conducted the Internet such as buying a ticket from the Web.

\subsection{Evaluation}

Anderson (in Arikunto ,2004, p.1) look Evaluation as a result of the process of determining who has achieved some planned activities to support the achievement of objectives. While Stufflebeam (in Arikunto, 2004, p.1), reveals that the evaluation is the process of depiction, search and providing useful information for decisionmaking in determining alternative. Stufflebeam CIPP model is one of the models used in the evaluation or management-oriented approach to decision-makers. Stufflebeam see evaluation as a process of describing, exploring and providing useful information for judging decision alternatives. The core concept CIPP is acronyms defined as an evaluation of a unity Context, Input, Process and Products (Stufflebeam, 2003, p.2).

\section{Methodology}

Referring to the purpose of this paper to describe the evaluation of e-ID card program in an effort to improve the quality of public services of Kediri City, the method used in this research is descriptive qualitative research method. In the study of e-ID card program evaluation using case study approach. This study aims to develop the most efficient methods of working, meaning the researchers conducted in-depth study of a particular case, the conclusion is valid only limited to specific cases.

\subsection{Data Collection Techniques}

Data was collected by means of intensive observations, conducted in-depth interviews and documentation techniques and review of the literature. To complement the primary data obtained in a manner as mentioned above, in this study also used secondary data.

\subsection{Data Analysis}

Technical analysis of the data in this study using the interactive analysis model in Miles and Huberman (1984) in Sugiyono (2010, p.92-99) following:

\subsubsection{Data Reduction}

The data obtained in the field is quite a lot, for it then it should be noted carefully and in detail. The longer the researchers in the field, the number of data is increasing, complex and complicated. For that we need to make 
data analysis through data reduction.

\subsubsection{Data Display}

Once the data is reduced, then the next step is display of data. The presentation of the data could be a short description, chart, relationships between categories, flowcharts and the like. In qualitative research, data presentation in the form of data compilation in the relationship, so it will be easily understood.

\subsubsection{Conclusion Drawing/Verification}

Preliminary conclusions presented are temporary, and will be changed if it is not found strong evidence that supports in step subsequent data collection. But if the conclusions presented in the early stages, supported by evidence and consistent when researchers returned to the field to collect the data, the conclusions put forward a credible conclusion.

\section{Result and Discussion}

4.1. Concept of the e-Service on the e-ID Card Program in the Efforts of Service Quality Improvement

\subsubsection{Concept of e-Service in e-ID Card Program}

Minister Regulation of Domestic Affairs No. 25 of 2011 about Guidelines for assessment, development and management of the information system on Population Administration Information System described the technology of e-ID card program. System based on e-ID card program is SOA (Service Oriented Architecture). SOA is an architectural style of make dan system using business processes in the form of a service pack. Ministry of Domestic Affair e-ID card and reguler e-ID cards used the same style by SOA. In the style of this Ministry, there is integration between services on a Central Government that was run by Ministry of Domestic Affair and Local Goverrnment run by Department of Population and Civil Registration Kediri City.

A Database is a collection of various types of population data stored systematically, structured and interlinked with the use of software, hardware and data communication networks. It can be noted that the publication of the e-ID card through some process, from process in Local Government, then to the Central Government, and then prints the results is sent to the Local Government in the Department of Population and Civil Registration Kediri City. As described by administrator software employee e-ID card program in the e-ID card program, the backdrop to technological advances in the creation of e-ID cards by NIK (Population Identification Number) so that no double ID card. This is for administrative order of population. Before the enactment of NIK, still using NIK District, this can lead to NIK lowest from local at district level to double. Since 2009, there were an online ID card data from the district centered in the Department of Population and Civil Registration Kediri City, but it could still double from different cities. The detection is done by recording the data covers, photograph, signature, iris and fingerprint. In the e-ID card data is there are five parameters namely, full name, mother's name, place, date of birth and gender.

Implementation of e-ID card is also to support good governance. With a single ID card, it will create good governance. Will get better service from government to society and its relation to the business/private sector, the public ID card can be used to deal with the private sector such as Bank, and others. Type of interaction in the eID card program in the Department of Population and civil registration takes place between sub-districts, and Ministry of Domestic Affair. Department of Population and Civil Registration interaction is, " publish " and " Interact ", G2C, G2B and G2G. While G2E still be used manually.

\subsubsection{Public Service Quality in E-ID Card Program}

\subsubsection{Tangible}

Therefore, establishing excellent service should beginning of the development of human beings who serve. Making services on e-ID card in Kediri City Department of Population and Civil Registration must quality, then the employee must actually have the human resources high ability in providing services. The are lack for Information and Technology expert, the most of from civil servant expert in law. Computer and equipment for taking photo fore-ID card in office is enough avaliable.

\subsubsection{Reliability}

Identity Card here in after abbreviated resident ID card is the official identification as proof of identity issued by the Department of Population and Civil Registration which valid throughout the territory of the Republic of Indonesia one of population document. With the publication of Kediri City Regulation No.7 of 2013 on the Implementation of Civil Affairs and printing costs Levies identity cards for residents of the town of Kediri who has aged 17 years or married, or never married are required to have ID cards. Some things that need to be 
understood about the ID card.

\subsubsection{Responsiveness}

Preparation activities include the Electronic ID Card Implementation Working Group Formation, Socialization, and Preparation Preparation Places HR (Human Resources) Services. All of these activities have been going well, and has formed the committee e-ID cards that can carry out their duties.

\subsubsection{Empathy}

From the observations and interviews with residents, empathy on population and civil registration offices in the e-ID card program or mass e-ID cards regularly, most of the residents stated that explain from Department of Population and Civil Registration directing them well. Residents served by a courteous and clear language.

\subsubsection{Assurance}

Residents properly directed, can guarantee the future for e-ID card reguler. But on implementation of e-ID regular no fixed date so, the possibility of incorrect data or missing in Ministry of Domestic Affairs still exists. Same also with the time of mass e-ID card. Based on SOP (Standard Operating Procedure) the e-ID Card program, sending data from the local government (Department of Population and Civil Registration) to the Center (Ministry of Domestic Affair) as follows: (1). Residents do recording e-ID cards in sub-district,, (2). Departement of Population and Civil Registration are placed in the transmit data online to Ministry of Domestic Affair, (3). Minisry of Domestic Affair verify, adjudification, cleansing data, printing, and shipping of data via post to Departement of Population and Civil Registration Kediri,and (4). Departement of Population and Civil Registration Kediri send to issuance e-ID card to every sub-district

Adjudification system is a way of finishing top of the form and character of the fingerprints are dubious because of the slope, vague, unclear, defective and damaged fingerprints. The database is a collection of various types of data stored in a systematic population, structured and interconnected using the software, hardware and data communication networks. Government had used e-government service. The Government Kediri City unlike the original which still use the service manual, there are 2 potential NIK (Population Identification Number) on a citizen, to reforms this, then there is no ID card doubles. For integrating with Ministry of Domestic Affair, Kediri City Government use SOA.

\subsection{Factor Supporting and Constraining the Electronic Identity Card Program}

\subsubsection{Internal Factor}

\subsubsection{1 . Infrastructure is not support .}

Despite the availability of sufficient computer 29. 29 Computer for e-ID card and 3 regular computer program in 3 sub-district. In the office there are 8 regular computer, 3 computers for e-ID card program, 3 regular computer is damaged. Constraints contained in the generator in the sub-district have not been there, only generator on Department of Population and Civil Registration alone. Besides supporting network is slow and faulty computer repair requires a long time.

\subsubsection{Organizational structure}

Department of Population and Civil Registration Kediri City has organizational structure consists of the Chairman, Vice Chairman, Secretary, Registration Division Population, Population Administration Information Systems and Civil Registration.

\subsubsection{The ability of employees}

The ability of employees to have good coordination. It can be seen from supervision on a daily basis by the district supervisor of Department of Population and Civil Registration. However, there are no employees who have special expertise in information technology, so if there is damage to tools still require the assistance of outside Department of Population and Civil Registration. Repair damaged equipment technology requires a long time.

\subsubsection{Socialization program .}

Socialization program done at sub-district and village residents at the beginning of a mass e ID card. During the regular dissemination of e-ID card is not done because of budget limitations. In the e-ID card program socialization and regular mass was giving a letter to the sub-village to alert citizens do mass e-ID card first time and regular e-ID card. Announcements about the procedures contained in the e-ID card village, sub-district and Department of Population and Civil Registration. However, knowledge about how to take care of the citizens of e-ID card only if delivered and explained to the parties of sub-village office organization to citizen. It is not to 
pamphlets distributed to facilitate the citizens know. Residents also do not know at the time of the e-ID card mass when his e-ID card so. They just finished a long wait. Similarly, e-mobile only be implemented on a mass e-ID card, the e-ID card is not implemented because of limited regular budget .

4.2.1.5. Timeliness in the creation of e-ID card

This time depends on the accuracy of the Ministry of Domestic Affairs to verify the data. Department of Population and Civil Registration Kediri City just waiting for ID cards distributed. One of the causes of good and bad service procedure is timeliness of service. This can be explained by the accuracy and timeliness of completion of the service process finish with what has been promised. There is no certainty of a clear time, like a few days e-ID is already finished and can be retrieved and no definite answer as to when e-ID card is made makes the timeliness of services provided by the Office management of manufacturing e-ID card is still not optimal. This is due to ignorance employee concerning the information provided by the central government. . 4.2.1.6. Population data privacy is maintained

In the e-ID card program contained a password on the computer operator. In addition, there is a Data Backup to avoid if at any time a natural disaster.

\subsubsection{External Factor}

\subsubsection{Public awareness for the orderly administration of residence}

Still there are people who do not make the e-ID card. They have not had need to take care of ID card. They do not care about the criminal sanctions of the local government

\subsubsection{Awareness agencies to hold a card reader}

Ministry of of Domestic Affair reminded all Ministry, Head of Non Government Organization, other Institutions Head, Chief of Police, the Governor of Bank Indonesia/The Leaders Bank, the Governor, the Regent/Mayor to Facilitate all work units/ business or other name on each line that provides service to the community, can provide a card reader in a short time, with the following explanation, if there is still work unit/entity or other names that provide services to the community, still photograph copy, staple and other treatments that destroy the physical eID card, will be given sanction in accordance with the legislation in force because it is very harmful to society , particularly the owner of the e-ID cards.

\section{Conclusion and Recommendation}

\subsection{Conclusion}

Ministry of Domestic Affair use Service Orientation Architecture (SOA) application for coordination with all Department of Population and Civil Regitration for e-ID card program, especially in Kediri City. Government ervice in e-ID card program is not effective on the improvement of public service quality. This program is just an interaction between local and central government, so there is no double e-ID card anymore. However, this program is doesn't make the easy procedure. This program has fulfilled four service attitudes and use good management. Although they can't be implemented tangible and assurance aspect.

5.2. Recommendation

Government can maximize data integration using SOA (Service Oriented Architecture) between the data for health, poverty, education and others. So far, only the Ministry of Domestic Affair only. Good service is necessary for public confidence in government. Government can immediately mobilize people to immediately make the data administration and the civil population if people already believe. The government should be more active conduct socialization to increase public awareness in the orderly administration of residence. E-mobile also needs to be held again for the service closer to the community. Citizen should keep a photo copy of ID card with reducing, copying from the copies of ID card just to keep the ID card of chip damage, and also prohibited staple of e-ID card .

\section{References}

Arikunto, Suharsimi and Cepi Safrudin Abdul Jabar. 2004. Program evaluation Education, Guidance for Practitioners Theoretical Education.Bumi Aksara. Jakarta

Bonansafm. Service of ID Card Dissapointed. 2012. www.bonansafm.com. Download at May, 5, 2013.

Hardiyansyah. 2011. Quality of Public Services: Concepts, Dimensions and indicators. Gava Media. Yogyakarta. Indrajit, Richardus Eko. 2002. Electronic Government Development Strategy and Development of Digital Technology Based Services. Second Edition. Andi Offset, Yogyakarta. 
Kartiwa and Nugraha. 2012. Government Authority Management. Editor Dadi J.Iskandar, Lesindo, Jakarta.

Law Number 32 Year 2004 about Local Government.

Law Number 23 Year 2006 about Population Administration

Minister Regulation of Domestic Affairs No. 25 of 2011 about Guidelines for assessment, development and management of the information system on Population Administration Information System

Presidential Instruction Number 6/2001 about Reference and Foundation of Telematics Development in Indonesia.

Local Regulation No. 7 of 2013 concerning the structure and size of the print cost recovery levy identity cards and civil registration certificate

Moenir, AS, 2006.Public Service Management in Indonesia. Jakarta;Bumi Aksara

Puspitosari, Hesti, et al. 2012. Philosophy Public Service. Second Edition. Setara Press. Malang.

Stufflebeam , L. Daniel . , 2003. The CIPP Model For Evaluation. Paper Presented on the 2003 Anual Conference of the Oregon Program Evaluation Network ( Open ). Portland, Oregon

Sugiyono. 2010. Qualitative Research Methods. Alfabeta. Bandung 
The IISTE is a pioneer in the Open-Access hosting service and academic event management. The aim of the firm is Accelerating Global Knowledge Sharing.

More information about the firm can be found on the homepage:

http://www.iiste.org

\section{CALL FOR JOURNAL PAPERS}

There are more than 30 peer-reviewed academic journals hosted under the hosting platform.

Prospective authors of journals can find the submission instruction on the following page: http://www.iiste.org/journals/ All the journals articles are available online to the readers all over the world without financial, legal, or technical barriers other than those inseparable from gaining access to the internet itself. Paper version of the journals is also available upon request of readers and authors.

\section{MORE RESOURCES}

Book publication information: http://www.iiste.org/book/

Recent conferences: http://www.iiste.org/conference/

\section{IISTE Knowledge Sharing Partners}

EBSCO, Index Copernicus, Ulrich's Periodicals Directory, JournalTOCS, PKP Open Archives Harvester, Bielefeld Academic Search Engine, Elektronische Zeitschriftenbibliothek EZB, Open J-Gate, OCLC WorldCat, Universe Digtial Library, NewJour, Google Scholar

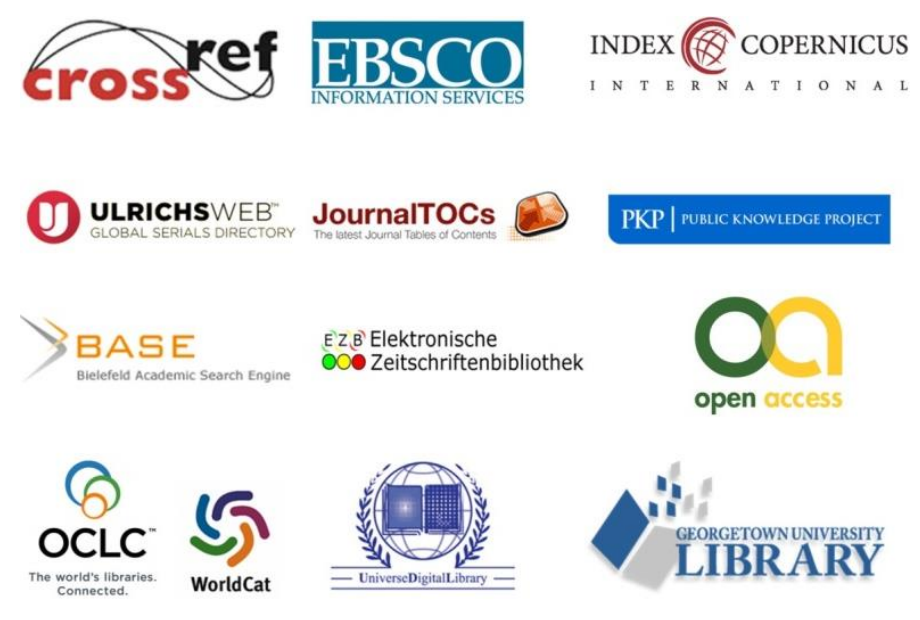

